\title{
Fat digestibility, nitrogen retention, and fatty acid profiles in blood and tissues of post-weaning piglets fed interesterified fats*
}

\author{
E.M. Straarup ${ }^{1,3}$, V. Danielsen ${ }^{2}$, K. Jakobsen ${ }^{2}$ and C.-E. Hoy ${ }^{1}$ \\ ${ }^{\prime}$ BioCentrum - DTU, Biochemistry and Nutrition, \\ Building 224, Technical University of Denmark \\ DK-2800 Lyngby, Denmark \\ ${ }^{2}$ Danish Institute of Agricultural Sciences, Research Centre Foulum, \\ Department of Animal Nutrition and Physiology \\ PO Box 50, DK-8830 Tjele, Denmark
}

(Received 28 October 2002; revised version 2 April 2003; accepted 15 July 2003)

\begin{abstract}
The effects of a designer fat as to changes in triacylglycerol structure in dietary fat on nutrient digestibility, nitrogen retention and fatty acid profile of plasma, erythrocyte membranes, liver, adipose tissue and skeletal muscle were examined in four groups of post-weaning piglets. The test fats added by $10 \%(\mathrm{w} / \mathrm{w})$ to the diets were: $\mathrm{R} 1$ regiospecific structured fats with decanoic acid mainly located in the sn- $1 / 3$ positions and a long-chain fatty acid from rapeseed oil in the sn- 2 position, R2 similar fat subjected to chemical randomization, R3 physical mixture of tridecanoin and rapeseed oil, and R4 rapeseed oil. The piglets were weaned at 28 days of age, and after one week of adaptation faeces and urine were collected quantitatively during three periods each of 7 days, in which the piglets were kept in metabolism cages for measurement of nutrient and energy digestibility and protein retention. Fat digestibility and nitrogen retention were improved significantly by feeding the manufactured oils containing 10:0 (R1-R3) compared to rapeseed oil ( $\mathrm{R} 4 ; \mathrm{P}<0.05$ ), with the highest improvement caused by the regiospecific oil (R1). The fatty acid profiles of plasma, erythrocyte membranes, liver, adipose tissue and skeletal muscle reflected the fatty acid profiles of the test fats, except for 10:0 which was only found in triacylglycerols in adipose tissue and blood plasma of R1-R3 in low concentrations, indicating that 10:0 was mainly oxidized providing energy for protein accretion.
\end{abstract}

KEY WORDS: rapeseed oil, decanoic acid, designer fat, long-chain fatty acids, medium-chain fatty acids

\footnotetext{
* Supported by grants from The Danish Ministry of Agriculture and Fisheries, Aarhus Oliefabrik A/S, Aarhus, Denmark and Association of Fish Meal and Fish oil Manuctures in Denmark

${ }^{3}$ Corresponding author: e-mail: ems@biocentrum.dtu.dk
} 


\section{INTRODUCTION}

Mortality is a major problem in large-scale production of piglets. Addition of fat to the sow diet in late gestation and during lactation often improves the survival rate of piglets (Pettigrew, 1981). This seems to be mediated through an increase in colostrum and milk fat (Morrison and Smith, 1964). Alternatively, supplemental fat may be offered the piglets by sow milk replacer. Pettigrew et al. (1986), however, did not observe an increased survival rate of newborn piglets fed maize oil in addition to sow milk.

Chwalibog et al. (1994) showed that the potential of post-weaning piglets for growth was so high that fat depots were utilized to support protein accretion and suggested addition of $8 \%$ fat to the diet to support their energy requirement. Chiang et al. (1990) demonstrated that unsuckled neonatal piglets utilized tricaprylin more efficiently than triolein, indicating a rapid hydrolysis of the medium-chain triacylglycerols by the preduodenal lipases compared to long-chain triacylglycerols as observed in rats (DeNigris et al., 1988) and piglets (Jensen et al., 1997). The medium-chain fatty acids supply energy to maintain a high nitrogen gain as demonstrated in rats (Teo et al., 1989). Long-chain fatty acids, including essential fatty acids, are necessary for the piglet, although in moderate amounts (Jakobsen, 1990). Dietary interesterified lipids containing medium-chain and long-chain fatty acids provide both energy and essential fatty acids. If these fats furthermore possess a regiospecific triacylglycerol structure with medium-chain fatty acids located in the primary positions and long-chain fatty acids in the secondary position of the triacylglycerol molecules, they are better substrates for the endogenous lipases compared to long-chain triacylglycerols (Jandacek et al., 1987; DeNigris et al., 1988). The faster hydrolysis of the triacylglycerols both by the preduodenal lipases and by pancreatic lipase will improve absorption of the lipid, even in the case of low secretion of pancreatic lipase, e.g. due to low activity of the pancreatic tissue (Christensen et al., 1995; Jensen et al., 1997).

An earlier study made in our laboratory with bile and pancreas diverted rats demonstrated a higher lymphatic transport of fatty acids in rats fed a regiospecific structured oil compared to a randomized oil, a physical mixture of soyabean oil, medium-chain triacylglycerols or a native soyabean oil (Christensen et al., 1995).

The aim of the present study was to further investigate if the improved absorption of a specific oil could increase the utilization of fat as energy source for protein accretion and the deposition of unsaturated fatty acids into liver, adipose tissue and skeletal muscle in post-weaning piglets. This would provide a possibility of designing dietary fat for improvement of health and vitality of pigs after weaning.

We manufactured four oils with different fatty acid distributions in the triacylglycerol molecule and fed them to piglets weaned at 28 days of age: R1 a 
regiospecific oil with 10:0 located in the sn-1/3 positions and long-chain fatty acids in the sn-2 position of the triacylglycerols, the long-chain fatty acids originating from rapeseed oil; R2 an oil with random distribution in the triacylglycerol of 10:0 and long-chain fatty acids from rapeseed oil; R3 physical mixture of tridecanoin and rapeseed oil, and R4 native rapeseed oil, which was used as control. Similar overall fatty acid profiles of the manufactured oils (R1-R3) were attempted. The influence of the dietary fats on nutrient digestibility, nitrogen retention, and the profiles of fatty acids in plasma, erythrocyte membranes, liver, adipose tissue and skeletal muscle were examined.

\section{MATERIAL AND METHODS}

\section{Animals}

From each of six litters of multiparous sows (alternating Danish Landrace x Yorkshire) 4 piglets of the same sex were selected and allocated on 4 different diets (i.e. 3 replicates with 4 castrated male piglets and 3 replicates with 4 female piglets). Before weaning, the piglets were housed in farrowing pens with the mother sow in an environmentally controlled building. The piglets had no access to creep feed while nursing. At weaning at 28 days of age blood samples were collected from vena jugularis by vein puncture into heparinized tubes. In the first week after weaning the piglets were adapted to their experimental feed in individual pens. Subsequently, three periods of each 7 days were undertaken of which 2 days were used for feed adjustment and 5 days for collection of faeces and urine for determination of the digestibility of nutrients and energy and the retention of protein. Initial body weight of the piglets averaged 9.0, 10.8 and $13.3 \mathrm{~kg}$ for period 1,2 and 3 , respectively. Daily feed allowances were 250,400 and $500 \mathrm{~g}$ per piglet in the three periods, respectively. Water was available at all time. At the end of the experiment plasma samples were collected and the piglets were killed by an overdose of pentobarbital (i.p. $10 \mathrm{ml}, 200 \mathrm{mg} / \mathrm{ml}$ ). After exsanguination samples of liver, adipose tissue from the backfat (all backfat from the neck to the rib was removed, and a sample for analysis was taken from the center), and skeletal muscle (M. longissimus dorsi) were quickly removed, frozen and kept at $-40^{\circ} \mathrm{C}$ until analyzed.

\section{Diets}

Each of the four test oils were added at a level of $10 \%$ to a basal diet consisting of (\%): barley 28.8 , wheat 28.8 , soyabean meal 17.0 , fish meal 12.0 , lysine- $40 \%$ premix 0.6 , feed chalk 0.4 , dicalcium phosphate 1.7 , salt 0.3 , micromineral-andvitamin mixture 0.4 . The chemical composition of the diets is shown in Table 1 . 
The diets were composed to fulfill the nutrient and energy requirements of piglets according to Danish Feeding Standards (The National Committee for Pig Breeding, Health and Production, 1997).

TABLE 1

Chemical composition of experimental diets

\begin{tabular}{lcccc}
\hline Diets & $\begin{array}{c}\text { Rapeseed/10:0 } \\
\text { specific } \\
(\mathrm{R} 1)\end{array}$ & $\begin{array}{c}\text { Rapeseed/tri 10:0 } \\
\text { randomized } \\
(\mathrm{R} 2)\end{array}$ & $\begin{array}{c}\text { Rapeseed/tri 10:0 } \\
\text { physical mixture } \\
(\mathrm{R} 3)\end{array}$ & $\begin{array}{c}\text { Rapeseed } \\
\text { oil } \\
\text { (R4) }\end{array}$ \\
\hline Dry matter (DM), g/100g & 89.7 & 89.6 & 89.8 & 89.7 \\
Ash, g/kg DM & 64 & 64 & 65 & 64 \\
Crude protein, g/kg DM & 262 & 264 & 267 & 267 \\
Crude fat, g/kg DM & 142 & 141 & 139 & 143 \\
Crude fibre, g/kg DM & 39 & 40 & 39 & 42 \\
NFE', g/kg DM & 493 & 491 & 490 & 484 \\
Gross energy, MJ/kg DM & 21.03 & 20.95 & 21.00 & 20.99 \\
\hline
\end{tabular}

${ }^{1}$ nitrogen-free extractives calculated as difference

\section{Dietary fats}

Rapeseed oil (Aarhus Oliefabrik A/S, Aarhus, Denmark), decanoic acid (Sigma Chemical, St. Louis, MO, USA) and tridecanoin (Grünau GmbH, Illertissen, Germany) were used as substrates for the lipase (Lipozyme IM, Novo Nordisk A/S, Denmark) catalyzed interesterification (Xu et al., 1998), the chemical interesterification and the mixing of oils to prepare the physical mixture. The interesterifications were performed as batch processes in a $40 \mathrm{~kg}$ level reactor.

The lipase catalyzed interesterification of rapeseed oil with decanoic acid resulted in a specific triacylglycerol structure with 10:0 mainly located in the sn-1/3 positions (R1), whereas the chemical interesterification, using sodium methoxide as catalyst, of rapeseed oil with tridecanoin resulted in a random distribution of the fatty acids in the triacylglycerol molecules (R2; Table 2). The physical mixture was manufactured by mixing rapeseed oil and tridecanoin (R3). The manufactured oils were constructed to attempt similar overall total fatty acid profiles, but with different triacylglycerol structures (Table 2).

\section{Digestibility and balance experiments}

The piglets were placed individually in metabolism cages of stainless steel (height $70 \mathrm{~cm}$ x width $55 \mathrm{~cm}$ x length $110 \mathrm{~cm}$ ) with $2 \mathrm{~mm}$ mesh wire. As 8 metabolism cages were available, the experiments were conducted in three rounds. In the first week after weaning the piglets were adapted to the feed, and subsequently three balance periods each of 7 days followed. In the first two days of each balance period the daily feed allocation was increased, whereupon it was kept constant 
TABLE 2

Fatty acid profiles in triacylglycerols and sn 2-monoacylglycerols of test oils ${ }^{1}$, mol/100 mol

\begin{tabular}{|c|c|c|c|c|}
\hline Fatty acid & $\begin{array}{l}\text { Rapeseed/10:0 } \\
{ }^{2} \text { specific } \\
\text { (R1) }\end{array}$ & $\begin{array}{c}\text { Rapeseed/tri 10:0 } \\
{ }^{3} \text { randomized } \\
\text { (R2) }\end{array}$ & $\begin{array}{l}\text { Rapeseed/tri 10:0 } \\
{ }^{4} \text { physical mixture } \\
\text { (R3) }\end{array}$ & $\begin{array}{c}\text { Rapeseed } \\
\text { oil } \\
\text { (R4) }\end{array}$ \\
\hline \multicolumn{5}{|c|}{ Triacylglycerols } \\
\hline $10: 0$ & 40.5 & 40.9 & 34.0 & $\mathrm{nd}^{5}$ \\
\hline $16: 0$ & 2.5 & 2.9 & 3.3 & 5.4 \\
\hline $16: 1 n-7$ & 0.1 & 0.1 & nd & 0.3 \\
\hline $18: 0$ & 1.1 & 1.1 & 1.2 & 1.7 \\
\hline $18: 1 n-9$ & 34.0 & 33.1 & 37.2 & 55.4 \\
\hline $18: 1 n-7$ & 1.7 & 1.9 & 2.2 & 3.5 \\
\hline $18: 2 n-6$ & 14.1 & 12.7 & 14.2 & 21.9 \\
\hline $18: 3 n-3$ & 4.5 & 5.8 & 6.4 & 9.7 \\
\hline $20: 0$ & 0.5 & 0.3 & 0.4 & 0.6 \\
\hline $20: 1 n-9$ & 0.7 & 0.7 & 0.8 & 1.1 \\
\hline $22: 0$ & 0.0 & 0.2 & 0.2 & 0.3 \\
\hline $22: 1 n-9$ & 0.2 & 0.2 & 0.2 & 0.2 \\
\hline \multicolumn{5}{|c|}{ sn 2-monoacylglycerols } \\
\hline 10:0 & 19.6 & 45.5 & 46.6 & nd \\
\hline $16: 0$ & 0.9 & 2.7 & 0.1 & 0.2 \\
\hline $16: 1 n-7$ & 0.1 & 0.1 & nd & 0.2 \\
\hline $18: 0$ & 0.3 & 1.0 & nd & 0.1 \\
\hline $18: 1 n-9$ & 42.5 & 30.5 & 25.7 & 47.3 \\
\hline $18: 1 n-7$ & 1.2 & 1.8 & 0.5 & 0.9 \\
\hline $18: 2 n-6$ & 26.1 & 11.6 & 18.4 & 35.2 \\
\hline $18: 3 n-3$ & 8.1 & 5.4 & 8.4 & 15.4 \\
\hline $20: 0$ & 0.8 & 0.3 & 0.1 & 0.3 \\
\hline $20: 1 n-9$ & 0.3 & 0.6 & nd & nd \\
\hline $22: 0$ & 0.2 & 0.1 & 0.1 & 0.3 \\
\hline $22: 1 n-9$ & nd & 0.2 & nd & 0.1 \\
\hline
\end{tabular}

${ }^{1}$ data represent the means of two determinations

${ }^{2}$ specific oil: 10:0 mainly in sn-1- and 3-positions and long chain fatty acid located in the sn-2 position of the triacylglycerol molecule

${ }^{3}$ randomized oil: similar to specific oil but with a random distribution of fatty acids in the triacylglycerol molecule

${ }^{4}$ physical mixture: mix of tridecanoin and rapeseed oil

${ }^{5}$ nd: not detectable

in the following 5 days where collection of faeces and urine was undertaken. Urine was collected in $50 \mathrm{ml} \mathrm{30 \%} \mathrm{sulphuric} \mathrm{acid} \mathrm{to} \mathrm{avoid} \mathrm{evaporative} \mathrm{loss} \mathrm{of} \mathrm{ammonia.}$ Faeces and urine were removed twice daily and pooled for each balance period. Urine was stored at $+4^{\circ} \mathrm{C}$ and faeces at $-20^{\circ} \mathrm{C}$ until the end of the experiments. The pooled samples were thoroughly mixed before aliquots were taken for analysis. 
Analysis of feed, faeces and urine

Samples of faeces were mixed and sub-samples were freeze-dried before analysis. Feed and faeces were analyzed for dry matter, crude fibre and crude ash according to AOAC (1990). Protein ( $\mathrm{N}$ x 6.25) was measured by the Kjeldahl method using Kjel-foss 16200 autoanalyzer (Foss Electric, Hillerod, Denmark). Fresh urine $(5 \mathrm{ml})$ was used for $\mathrm{N}$ determination. Fat was extracted with petrol ether after hydrochloric acid hydrolysis (Stoldt, 1952). Gross energy in feed and faeces was determined by bomb calorimetry.

\section{Analysis of oil lipid}

Fatty acid methylesters were prepared through transesterification catalyzed by $\mathrm{KOH}$ in methanol (Christopherson and Glass, 1969). Following addition of $\mathrm{NaHCO}_{3}$ and centrifugation at $4000 \mathrm{rpm}$ for $15 \mathrm{~min}$ (Heraeus Sepatech Megafuge 1.0, Holm and Halby A/S, Allerod, Denmark), the fatty acid methylesters dissolved in heptane were analyzed by gas-liquid chomatography using a Hewlett-Packard 5890 series II chromatograph with flame-ionization detection (Hewlett-Packard GmbH, Ingelsheim, Germany), and a fused silica capillary column (SP-2380, $60 \mathrm{~m}$, ID $0.25 \mathrm{~mm}$, Supelco, Bellefonte, PA, USA). Carrier gas was helium. A split ratio of 1:14.6 was applied. The initial column flow rate was $1.2 \mathrm{~mL} / \mathrm{min}$. The initial oven temperature was $70^{\circ} \mathrm{C}$ for 0.5 min and temperature programming was as follows: $15^{\circ} \mathrm{C} / \mathrm{min}$ to $160^{\circ} \mathrm{C}, 1.5^{\circ} \mathrm{C} / \mathrm{min}$ to $200^{\circ} \mathrm{C}$, which was maintained for $15 \mathrm{~min}$ followed by a rate of $30^{\circ} \mathrm{C} / \mathrm{min}$ to $225^{\circ} \mathrm{C}$, which was maintained for $5 \mathrm{~min}$. Fatty acids from 6:0 to 22:6n-3 were identified if present from retention times of actual standards (NU-CHEK Prep., Inc., Elysian, Minnesota, USA).

Regiospecific analysis of the dietary oil was performed by degradation with allylmagnesium bromide as Grignard reagent (Becker et al., 1993). The sn 2 monoacylglycerol fraction was isolated by thin layer chromatography on boric acid impregnated thin layer chromatography plates developed twice ( 2 x $60 \mathrm{~min}$ ) in chloroform:acetone $(90: 10 \mathrm{v} / \mathrm{v})$, methylated, and analyzed by gas-liquid chromatography as described here.

\section{Analysis of blood samples}

Plasma samples were kept at $-20^{\circ} \mathrm{C}$ until analyzed. Total lipids were extracted according to Folch et al. (1957). Erythrocytes were isolated by centrifugation with Lymphoprep (Nycomed Pharma A/S, Oslo, Norway) and kept in chloroform: methanol $(95: 5+0.05 \% \mathrm{BHT})$ at $-40^{\circ} \mathrm{C}$ until analyzed. Total lipids of erythrocyte membranes were extracted according to Bligh and Dyer (1959). Internal standards were 15:0 as triacylglycerol and phosphatidylcholine (Sigma Chemical, St. Louis, MO) added to total lipids. 
Triacylglycerols and total phospholipids of plasma and erythrocyte membranes were separated by thin-layer chromatography and methylated by transesterification catalyzed by $\mathrm{KOH}$ in methanol (Christopherson and Glass, 1969). The fatty acid methylesters from 6:0 to 22:6n-3 were analyzed and identified as described for dietary oil lipids.

\section{Analysis of tissue lipids}

Samples (approx. $0.5 \mathrm{~g}$ ) of liver, adipose tissue from backfat and skeletal muscle (M. longissimus dorsi) were homogenized and total lipids were extracted according to Folch et al. (1957). Internal standards were 15:0 as triacylglycerol and phosphatidylcholine (Sigma Chemical, St. Louis, MO) added after homogenization. Triacylglycerols and total phospholipids of liver, adipose tissue, and skeletal muscle were separated and analyzed as described for blood samples. Fatty acids from 6:0 to 22:6n-3 were identified if present.

\section{Statistical analysis}

Results were expressed as LS means \pm SEM. Analysis of variance was made using the GLM procedure (SAS ${ }^{\circledR}$ Institute, Gary, NC, USA) with the effect of diet as main effect and adjusting for the effect of period and replicate. When significant effects were obtained $(\mathrm{P}<0.05)$, differences between means were compared by P-DIFF on LS-Means (SAS $\left.{ }^{2}, 1987\right)$.

\section{RESULTS}

\section{Performance}

As shown in Table 1 the chemical composition of the four diets was similar with 262-267 g protein per kg dry matter (DM) and $21 \mathrm{MJ}$ gross energy per kg DM. The esterifications of the rapeseed oil with 10:0 were attempted to give similar proportions of 10:0 and 18:2n-6 in triacylglycerols. This was almost achieved as shown in Table 2. In the sn-2monoacylglycerols a lower proportion of 10:0 was achieved for R1 as compared to R2 and R3, which were similar (19.6 vs $46 \mathrm{~mol} / 100 \mathrm{~mol}$ ), which demonstrates the structural differences of the oils. In the latter case more $18: 2 \mathrm{n}-6$ was found for R1 $(26.1 \mathrm{~mol} / 100 \mathrm{~mol})$ than for R2 $(11.6 \mathrm{~mol} / 100 \mathrm{~mol})$ and R3 (18.4 mol/100 mol).

The mean liveweight ( $\mathrm{LW} \pm \mathrm{SEM}$ ) of the piglets at the beginning of week 1, 2 and 3 was $9.03 \pm 0.34,10.8 \pm 0.32$ and $13.3 \pm 0.31 \mathrm{~kg}$, respectively. At the end of the experiment the LW was on average $15.7 \pm 0.31 \mathrm{~kg}$, and no significant differen- 
ces in LW between groups were found. All piglets fulfilled the scheduled collection periods (a total of 72), but one period (litter no. 4, feed mixture R2, period 1) had to be omitted from the calculations due to abnormal digestibility coefficients.

\section{Digestibility of nutrients and protein retention}

The overall results of the three balance periods are shown in Table 3. No significant differences between groups were found in the digestibility of dry matter (variation 85.4-85.8\%), protein (84.9-85.8\%), crude fibre (48.4-52.1\%) and NFE (91.8-92.2\%). However, fat digestibility was significantly lower for the rapeseed oil group (R4) than for the manufactured oils of rapeseed oil and 10:0 (R1-R3) (80.2 vs $83.9 \%)$. The digestibility of energy was significantly lower for R4 but only in comparison to R2. Protein retention was significantly lower for the rapeseed oil fed group (54.9 g/day) compared to the groups fed the specific structured oil (R1) with $58.6 \mathrm{~g}$ /day and the randomized structured oil (R2) with $57.8 \mathrm{~g} /$ day $(\mathrm{P}<0.05)$, but similar to that of the group fed the physical mixture (R3). In per cent of digested protein the differences were further accentuated as seen in Table 3. Metabolizable energy ranged between $17.03 \mathrm{MJ} / \mathrm{kg} \mathrm{DM}$ for R4 to 17.35 $\mathrm{MJ} / \mathrm{kg} \mathrm{DM}$ for R2 $(\mathrm{P}<0.05)$.

TABLE 3

Overall digestibility of nutrients, protein retention and metabolizable energy in piglets fed the experimental diets for 3 weeks (LS-means and SEM)

\begin{tabular}{|c|c|c|c|c|c|}
\hline Diets & $\begin{array}{l}\text { Rapeseed } / 10: 0 \\
\text { specific } \\
\text { (R1) }\end{array}$ & $\begin{array}{l}\text { Rapeseed/tri 10:0 } \\
\text { randomized } \\
(\mathrm{R} 2)\end{array}$ & $\begin{array}{c}\text { Rapeseed/tri 10:0 } \\
\text { physical mixture } \\
\text { (R3) }\end{array}$ & $\begin{array}{c}\text { Rapeseed } \\
\text { oil } \\
\text { (R4) }\end{array}$ & SEM $^{1}$ \\
\hline No of observations & 24 & 23 & 24 & 24 & \\
\hline \multicolumn{6}{|l|}{ Digestibility, \% } \\
\hline dry matter & 85.6 & 85.8 & 85.7 & 85.4 & 0.4 \\
\hline protein & 84.9 & 85.7 & 85.2 & 85.8 & 0.6 \\
\hline fat & $84.3^{\mathrm{b}}$ & $84.1^{\mathrm{b}}$ & $83.2^{\mathrm{b}}$ & $80.2^{\mathrm{a}}$ & 1.0 \\
\hline crude fibre & 48.4 & 49.4 & 50.9 & 52.1 & 1.8 \\
\hline $\mathrm{NFE}^{2}$ & 91.8 & 92.1 & 92.2 & 91.9 & 0.4 \\
\hline energy & $85.5^{\mathrm{ab}}$ & $85.9^{\mathrm{b}}$ & $85.7^{\mathrm{ab}}$ & $84.7^{\mathrm{a}}$ & 0.4 \\
\hline \multicolumn{6}{|l|}{ Protein retention } \\
\hline average, g/day & $58.6^{\mathrm{b}}$ & $57.8^{\mathrm{b}}$ & $56.2^{\mathrm{ab}}$ & $54.9^{\mathrm{a}}$ & 1.0 \\
\hline$\%$ of digested protein & $75.0^{\mathrm{c}}$ & $72.8^{\mathrm{bc}}$ & $70.9^{\mathrm{ab}}$ & $68.6^{\mathrm{a}}$ & 1.2 \\
\hline $\begin{array}{l}\text { Metabolizable energy, } \\
\mathrm{MJ} / \mathrm{kg} \text { DM }\end{array}$ & $17.29^{\mathrm{ab}}$ & $17.35^{\mathrm{b}}$ & $17.28^{\mathrm{ab}}$ & $17.03^{\mathrm{a}}$ & 0.09 \\
\hline
\end{tabular}

${ }^{1}$ standard error of means

${ }^{2}$ nitrogen-free extractives

a,b,c superscripts in the same row with different letters are significantly different $(\mathrm{P}<0.05)$ 
TABLE 4

Fat digestibility and nitrogen retention during each of 3 weeks on weaning diets ${ }^{1}$

\begin{tabular}{|c|c|c|c|c|c|}
\hline Diets & $\begin{array}{c}\text { Rapeseed/tri 10:0 } \\
\text { specific } \\
(\mathrm{R} 1)\end{array}$ & $\begin{array}{c}\text { Rapeseed/tri 10:0 } \\
\text { randomized } \\
(\mathrm{R} 2)\end{array}$ & $\begin{array}{c}\text { Rapeseed/tri 10:0 } \\
\text { physical mixture } \\
(\mathrm{R} 3)\end{array}$ & $\begin{array}{c}\text { Rapeseed } \\
\text { oil } \\
(\mathrm{R} 4) \\
\end{array}$ & SEM \\
\hline \multicolumn{6}{|c|}{ Fat digestibility, $\%^{2}$} \\
\hline week 1 & $82.2^{\mathrm{a}}$ & $80.7^{\mathrm{a}, 1}$ & $76.1^{\mathrm{ab}, 1}$ & $73.7^{\mathrm{b}, 1}$ & 2.1 \\
\hline week 2 & 84.8 & $84.4^{12}$ & $86.3^{2}$ & $85.0^{2}$ & 0.9 \\
\hline week 3 & $86.0^{\mathrm{a}}$ & $87.0^{\mathrm{a}, 2}$ & $87.1^{\mathrm{a}, 2}$ & $81.9^{\mathrm{b}, 2}$ & 0.7 \\
\hline \multicolumn{6}{|c|}{ Nitrogen retention in $\%$, of digested } \\
\hline week 1 & $69.9^{\mathrm{a}, 1}$ & $68.3^{\mathrm{ab}, 1}$ & $64.2^{\mathrm{ab}, 1}$ & $60.6^{\mathrm{b}, 1}$ & 2.8 \\
\hline week 2 & $77.1^{\mathrm{a}, 2}$ & $74.1^{\mathrm{ab}, 2}$ & $74.3^{\mathrm{ab}, 2}$ & $72.9^{\mathrm{b}, 2}$ & 1.2 \\
\hline week 3 & $77.9^{\mathrm{a}, 2}$ & $76.8^{\mathrm{a}, 2}$ & $74.2^{\mathrm{ab}, 2}$ & $71.5^{\mathrm{b}, 2}$ & 1.4 \\
\hline \multicolumn{6}{|c|}{$\begin{array}{l}1 \text { data represent LS-means for } 6 \text { determinations } \pm \text { standard error of the mean (SEM) except for R2 } \\
\text { week one with only } 5 \text { determinations }\end{array}$} \\
\hline
\end{tabular}

Table 4 shows the digestibility of fat and nitrogen retention in relation to digested protein for each balance period. The latter expresses the biological value (BV) of the protein. Fat digestibility from week 1 to week 2 was significantly improved in group $\mathrm{R} 3$ and $\mathrm{R} 4(\mathrm{P}<0.05)$. The improvement was maintained through week 3 . In group R2 the fat digestibility improved significantly from week 1 to week 3 , whereas no change was observed in group R1 during the three weeks. The latter observation may be due to the high fat digestibility in group R1 at the beginning of the collection periods.

Fat digestibility was improved after the first week in piglets fed the R1 and $\mathrm{R} 2$ diets compared to those fed the $\mathrm{R} 4 \operatorname{diet}(\mathrm{P}<0.05)$. In the second week the fat digestibility was similar in all four groups (84-86\%). In the third week the fat digestibility in piglets fed the R4 diet decreased and was lowest (81.9\%), whereas it still increased in the other three groups (R1, R2 and R3) to a similar level of $86-87 \%$.

Nitrogen retention in percent of digested nitrogen was markedly improved from the first to the second week of the experiment in all 4 groups $(\mathrm{P}<0.05)$. After the first week a difference of $15.3 \%(\mathrm{P}<0.05)$ between the $\mathrm{R} 1$ and $\mathrm{R} 4$ diets was observed and after 3 weeks the difference was still $9 \%$ and also a significant difference between the R2 and R4 diets of $7.4 \%$ was observed.

\section{Fatty acid profiles of phospholipids and triacylglycerols}

Liver. The fatty acid profile of both phospholipids and triacylglycerols reflected the profiles of the test oils as observed in the liver from piglets fed the R4 diet, 
which had a higher proportion of 18:1 and 18:3n-3 in phospholipids and triacylglycerols compared to the other groups $(\mathrm{P}<0.05$; Table 5). However the much higher content of these fatty acids in the R4 test fat was not fully reflected in the liver when compared to the other test fats.

TABLE 5

Fatty acid profile of phospholipids and triacylglycerols in liver of pigs at the end of the experimental period $^{1}$

\begin{tabular}{|c|c|c|c|c|c|}
\hline Diets & $\begin{array}{c}\text { Rapeseed/10: } \\
0 \text { specific } \\
(\mathrm{R} 1)\end{array}$ & $\begin{array}{c}\text { Rapeseed/tri 10:0 } \\
\text { randomized } \\
(\mathrm{R} 2)\end{array}$ & $\begin{array}{c}\text { Rapeseed/tri 10:0 } \\
\text { physical mixture } \\
\text { (R3) }\end{array}$ & $\begin{array}{c}\text { Rapeseed } \\
\text { oil } \\
\text { (R4) }\end{array}$ & SEM \\
\hline & \multicolumn{5}{|c|}{ mole/100 mole } \\
\hline \multicolumn{6}{|c|}{ Phospholipids } \\
\hline $10: 0$ & $\mathrm{nd}^{2}$ & nd & nd & nd & \\
\hline $14: 0$ & 0.1 & 0.2 & 0.3 & 0.1 & 0.0 \\
\hline $16: 0$ & $13.2^{\mathrm{ac}}$ & $14.0^{\mathrm{ab}}$ & $14.3^{\mathrm{b}}$ & $12.7^{\mathrm{c}}$ & 0.4 \\
\hline $16: 1 n-7$ & 0.6 & 0.6 & 0.7 & 0.6 & 0.0 \\
\hline $18: 0$ & $26.5^{\mathrm{a}}$ & $26.9^{\mathrm{a}}$ & $26.2^{\mathrm{ab}}$ & $24.6^{\mathrm{b}}$ & 0.6 \\
\hline $18: \ln -9$ & $12.6^{\mathrm{a}}$ & $11.7^{\mathrm{a}}$ & $11.9^{\mathrm{a}}$ & $14.0^{\mathrm{b}}$ & 0.3 \\
\hline $18: 1 n-7$ & $2.8^{\mathrm{a}}$ & $2.9^{\mathrm{a}}$ & $2.8^{\mathrm{a}}$ & $3.6^{\mathrm{b}}$ & 0.1 \\
\hline $18: 2 n-6$ & 15.7 & 15.3 & 15.2 & 15.9 & 0.2 \\
\hline $18: 3 n-3$ & $0.7^{\mathrm{a}}$ & $0.9^{\mathrm{ab}}$ & $1.0^{\mathrm{b}}$ & $1.0^{\mathrm{b}}$ & 0.1 \\
\hline $20: 3 n-6$ & 1.1 & 0.8 & 0.8 & 0.8 & 0.1 \\
\hline $20: 4 n-6$ & $10.1^{\mathrm{ac}}$ & $9.6^{\mathrm{ab}}$ & $9.5^{\mathrm{b}}$ & $10.3^{\mathrm{c}}$ & 0.2 \\
\hline $20: 5 n-3$ & $6.2^{\mathrm{a}}$ & $6.7^{\mathrm{ab}}$ & $7.0^{\mathrm{b}}$ & $6.6^{\mathrm{ab}}$ & 0.2 \\
\hline $22: 5 n-3$ & $1.7^{\mathrm{a}}$ & $1.8^{\mathrm{b}}$ & $1.8^{\mathrm{b}}$ & $1.9^{\mathrm{b}}$ & 0.1 \\
\hline $22: 6 n-3$ & 7.6 & 7.7 & 7.7 & 6.8 & 0.2 \\
\hline \multicolumn{6}{|c|}{ Triacylglycerols } \\
\hline $10: 0$ & $\mathrm{Nd}$ & nd & nd & nd & \\
\hline $14: 0$ & $1.2^{\mathrm{a}}$ & $1.1^{\mathrm{a}}$ & $1.3^{\mathrm{a}}$ & $0.8^{\mathrm{b}}$ & 0.1 \\
\hline $16: 0$ & $16.5^{\mathrm{a}}$ & $15.3^{\mathrm{ab}}$ & $16.2^{\mathrm{a}}$ & $14.3^{\mathrm{b}}$ & 0.5 \\
\hline $16: 1 \mathrm{n}-7$ & $2.9^{\mathrm{a}}$ & $2.1^{\mathrm{b}}$ & $3.1^{\mathrm{a}}$ & $2.1^{\mathrm{b}}$ & 0.2 \\
\hline $18: 0$ & $6.8^{\mathrm{a}}$ & $6.6^{\mathrm{a}}$ & $5.6^{\mathrm{b}}$ & $6.1^{\mathrm{ab}}$ & 0.3 \\
\hline $18: \ln -9$ & $33.2^{\mathrm{a}}$ & $32.0^{\mathrm{a}}$ & $33.8^{\mathrm{ab}}$ & $35.8^{\mathrm{b}}$ & 0.7 \\
\hline $18: 1 \mathrm{n}-7$ & 3.1 & 3.1 & 3.0 & 3.3 & 0.1 \\
\hline $18: 2 n-6$ & 18.9 & 19.0 & 18.3 & 18.8 & 0.5 \\
\hline $18: 3 n-3$ & $3.8^{\mathrm{a}}$ & $4.4^{\mathrm{ab}}$ & $4.7^{b}$ & $4.2^{\mathrm{ab}}$ & 0.3 \\
\hline $20: 3 n-6$ & $0.6^{\mathrm{ab}}$ & $0.7^{\mathrm{a}}$ & $0.5^{\mathrm{b}}$ & $0.5^{\mathrm{b}}$ & 0.0 \\
\hline $20: 4 n-6$ & $4.6^{\mathrm{ab}}$ & $5.1^{\mathrm{a}}$ & $3.9^{\mathrm{b}}$ & $4.9^{\mathrm{a}}$ & 0.3 \\
\hline $20: 5 n-3$ & $3.5^{\mathrm{a}}$ & $4.4^{\mathrm{b}}$ & $3.9^{\mathrm{ab}}$ & $3.9^{\mathrm{ab}}$ & 0.2 \\
\hline $22: 5 n-3$ & $1.6^{\mathrm{a}}$ & $2.2^{\mathrm{b}}$ & $1.9^{\mathrm{ab}}$ & $1.9^{\mathrm{ab}}$ & 0.1 \\
\hline $22: 6 n-3$ & $2.6^{\mathrm{a}}$ & $3.3^{\mathrm{b}}$ & $3.0^{\mathrm{ab}}$ & $2.5^{\mathrm{a}}$ & 0.2 \\
\hline
\end{tabular}

${ }^{1}$ values represent LS-means \pm SEM $(n=6)$

${ }^{2}$ nd: not detectable

fatty acids represented with less than $1 \mathrm{~mole} \%$ in both the phospholipid and

triacylglycerol fractions are not shown

total fatty acids identified equals $100 \mathrm{~mole} \%$

values in a row without common superscript letters are different $(\mathrm{P}<0.05)$ 
Adipose tissue. In backfat phospholipids the proportion of 18:1n-9 in the R4 group was higher than in the other groups $(\mathrm{P}<0.05$; Table 6). Furthermore, the $\mathrm{R} 1$ group had a higher proportion of 18:1n-9 than the R2 and R3 groups $(\mathrm{P}<0.05)$, although the proportion of this fatty acid in the R1 oil was lower than in the R3 oil

TABLE 6

Fatty acid profiles of phospholipids and triacylglycerols of adipose tissue from backfat of pigs at the end of the experimental period ${ }^{1}$

\begin{tabular}{|c|c|c|c|c|c|}
\hline Diets & $\begin{array}{l}\text { Rapeseed/10:0 } \\
\text { specific } \\
\text { (R1) }\end{array}$ & $\begin{array}{c}\text { Rapeseed/tri 10:0 } \\
\text { randomized } \\
(\mathrm{R} 2)\end{array}$ & $\begin{array}{c}\text { Rapeseed/tri 10:0 } \\
\text { physical mixture } \\
(\mathrm{R} 3)\end{array}$ & $\begin{array}{c}\text { Rapeseed } \\
\text { oil } \\
\text { (R4) }\end{array}$ & SEM \\
\hline \multicolumn{6}{|c|}{ Phospholipids } \\
\hline 10:0 & $\mathrm{nd}^{2}$ & nd & nd & nd & \\
\hline $14: 0$ & $0.5^{\mathrm{ab}}$ & $0.6^{\mathrm{a}}$ & $0.4^{\mathrm{b}}$ & $0.5^{\mathrm{ab}}$ & 0.0 \\
\hline $16: 0$ & $13.4^{\mathrm{ab}}$ & $13.8^{\mathrm{a}}$ & $12.1^{\mathrm{b}}$ & $13.7^{\mathrm{a}}$ & 0.5 \\
\hline $16: 1 n-7$ & $1.1^{\mathrm{a}}$ & $0.9^{\mathrm{ab}}$ & $0.8^{\mathrm{ab}}$ & $0.8^{\mathrm{b}}$ & 0.1 \\
\hline $18: 0$ & $27.8^{\mathrm{a}}$ & $28.5^{\mathrm{ab}}$ & $29.4^{\mathrm{b}}$ & $26.6^{\mathrm{c}}$ & 0.6 \\
\hline $18: 1 n-9$ & $17.8^{\mathrm{a}}$ & $16.6^{\mathrm{b}}$ & $16.0^{\mathrm{b}}$ & $19.2^{\mathrm{c}}$ & 0.3 \\
\hline $18: 1 n-7$ & $3.0^{\mathrm{ab}}$ & $2.5^{\mathrm{a}}$ & $2.5^{\mathrm{a}}$ & $3.1^{\mathrm{b}}$ & 0.2 \\
\hline $18: 2 n-6$ & 20.9 & 20.9 & 22.0 & 20.1 & 0.5 \\
\hline $18: 3 n-3$ & $1.2^{\mathrm{a}}$ & $1.4^{\mathrm{ab}}$ & $1.5^{\mathrm{ab}}$ & $1.7^{\mathrm{b}}$ & 0.1 \\
\hline $20: 3 n-6$ & 1.2 & 1.5 & 1.3 & 1.0 & 0.2 \\
\hline $20: 4 n-6$ & 6.4 & 6.7 & 6.7 & 6.6 & 0.3 \\
\hline $20: 5 n-3$ & 3.0 & 3.3 & 3.5 & 2.9 & 0.2 \\
\hline $22: 5 n-3$ & 1.2 & 1.3 & 1.2 & 1.3 & 0.1 \\
\hline $22: 6 n-3$ & 1.4 & 1.3 & 1.4 & 1.6 & 0.1 \\
\hline \multicolumn{6}{|c|}{ Triacylglycerols } \\
\hline $10: 0$ & $0.7^{\mathrm{ab}}$ & $0.4^{\mathrm{a}}$ & $1.4^{\mathrm{b}}$ & $0.0^{\mathrm{c}}$ & 0.2 \\
\hline $14: 0$ & $2.5^{\mathrm{a}}$ & $2.4^{\mathrm{a}}$ & $2.5^{\mathrm{a}}$ & $2.1^{b}$ & 0.1 \\
\hline $16: 0$ & 24.6 & 25.2 & 25.8 & 24.5 & 0.5 \\
\hline $16: 1 n-7$ & 6.3 & 6.2 & 6.7 & 6.9 & 0.1 \\
\hline $18: 0$ & 6.1 & 6.9 & 6.3 & 5.8 & 0.4 \\
\hline $18: \ln -9$ & $38.1^{\mathrm{a}}$ & $37.8^{\mathrm{a}}$ & $36.7^{\mathrm{b}}$ & $39.2^{\mathrm{c}}$ & 0.3 \\
\hline $18: 1 n-7$ & 4.0 & 4.1 & 4.2 & 4.2 & 0.1 \\
\hline $18: 2 n-6$ & 13.0 & 11.8 & 11.6 & 12.4 & 0.6 \\
\hline $18: 3 n-3$ & 2.2 & 2.3 & 2.2 & 2.7 & 0.3 \\
\hline $20: 3 n-6$ & nd & nd & nd & nd & \\
\hline $20: 4 n-6$ & $0.2^{\mathrm{a}}$ & $0.2^{\mathrm{b}}$ & $0.2^{\mathrm{ac}}$ & $0.2^{\mathrm{c}}$ & 0.0 \\
\hline $20: 5 n-3$ & 0.2 & 0.2 & 0.1 & 0.1 & 0.0 \\
\hline $22: 5 n-3$ & 0.3 & 0.3 & 0.3 & 0.3 & 0.0 \\
\hline $22: 6 n-3$ & 0.6 & 0.6 & 0.6 & 0.4 & 0.1 \\
\hline
\end{tabular}

${ }^{1}$ values represent LS-means \pm SEM $(n=6)$

${ }^{2}$ nd: not detectable

fatty acids represented with less than 1 mole $\%$ in both the phospholipid and

triacylglycerol fractions are not shown

total fatty acids identified equals 100 mole $\%$

values in a row without common superscript letters are different $(\mathrm{P}<0.05)$ 
and similar to than in the R2 oil. This however, reflects the proportion of 18:1n-9 in the sn-2 position. The adipose tissue triacylglycerols had a higher proportion of $18: 1 \mathrm{n}-9$ in the $\mathrm{R} 4$ group than in the other groups $(\mathrm{P}<0.05)$. The fatty acid 10:0 was detected only in adipose tissue triacylglycerols but at low proportions compared to the test fats. In the R3 group the proportion of 10:0 was higher than in the R2 group $(\mathrm{P}<0.05)$ and similar to the $\mathrm{R} 1$ group, although the $\mathrm{R} 3$ oil contained less 10:0 compared to the other two oils. No 10:0 was detectable in the R4 group.

Skeletal muscle. In skeletal muscle 10:0 was not detectable at all (Table 7). There was a significantly lower proportion of 16:0, 18:1n-7, 18:2n-6, 22:5n-3 and 22:6n-3 in phospholipids from piglets fed the $\mathrm{R} 2$ diet than in the other groups $(\mathrm{P}<0.05)$. Furthermore, the proportion of 14:0, 16:1n-7, 18:0 and 20:3n-6 was higher in the R2 group compared to the other groups. The proportion of 18:3n-3 was lower in the $\mathrm{R} 1$ and $\mathrm{R} 2$ groups than in the $\mathrm{R} 3$ and $\mathrm{R} 4$ groups $(\mathrm{P}<0.05)$.

In the triacylglycerols, the fatty acid 18:0 was lower represented in the R4 group, although the proportion of this fatty acid in the R4 oil was higher than in the other oils.

Plasma. Similar proportions of most of the fatty acids identified in the initial blood samples were observed (Table 8). In the phospholipids, however, exceptions were for 14:0, 16:0 and 16:1n-7, where small differences were observed between the initial sample: 14:0 were higher in the R3 group compared to the R2 group, 16:0 and 16:1n-7 were higher in the R2 group compared to the R3 and R4 groups. Thus the differences observed in the final samples of phospholipids for fatty acids other than 14:0, 16:0 and 16:1n-7 was expected to result from feeding the different test fats.

The R1, R2 and R3 oils contained 10:0. The presence of 10:0 in these oils was reflected in plasma triacylglycerols to similar extents in all three groups. However, 10:0 was not detectable in plasma phospholipids in any of these groups. From the start to the end of the experiment the proportions of 14:0, 16:0, 16:1n-7 and 20:4n-6 decreased and the proportions of 18:1n-9, 18:2n-6, 18:3n-3 and 20:5n-3 increased in all groups both in phospholipids and triacylglycerols.

The proportion of 18:1n-9 in total plasma phospholipids from piglets fed the R4 diet was higher than by feeding the $\mathrm{R} 2$ and $\mathrm{R} 3$ diets $(\mathrm{P}<0.05)$. The proportion of $18: 3 n-3$ was lower in piglets fed the $\mathrm{R} 1$ diet compared to the other groups $(\mathrm{P}<0.05)$.

In plasma triacylglycerols differences in the initial samples were observed for 18:1n-9, 18:1n-7 and 22:6n-3. Significantly lower proportions of 18:1 and 22:6 were observed in the R3 group compared to the R2 group. In the final samples these differences had disappeared but differences between the R4 and the other groups appeared for 18:1n-9 and 18:1n-7 ( $\mathrm{P}<0.05$; Table 8) reflecting the content of these fatty acids in the test oils. Significant differences $(\mathrm{P}<0.05)$ between the groups 
TABLE 7

Fatty acid profiles of phospholipids and triacylglycerols in skeletal muscle (M. longissimus dorsi) of pigs at the end of the experimental period ${ }^{1}$

\begin{tabular}{|c|c|c|c|c|c|}
\hline Diets & $\begin{array}{c}\text { Rapeseed/10:0 } \\
\text { specific } \\
\text { (R1) }\end{array}$ & $\begin{array}{c}\text { Rapeseed/tri10:0 } \\
\text { randomized } \\
(\mathrm{R} 2)\end{array}$ & $\begin{array}{l}\text { Rapeseed/tri10:0 } \\
\text { physical mixture } \\
\text { (R3) }\end{array}$ & $\begin{array}{c}\text { Rapeseed } \\
\text { oil } \\
\text { (R4) }\end{array}$ & SEM \\
\hline \multicolumn{6}{|c|}{ Phospholipids } \\
\hline 10:0 & $\mathrm{nd}^{2}$ & nd & nd & nd & \\
\hline $14: 0$ & $0.3^{\mathrm{a}}$ & $0.6^{\mathrm{b}}$ & $0.2^{\mathrm{a}}$ & $0.2^{\mathrm{a}}$ & 0.1 \\
\hline $16: 0$ & $20.4^{\mathrm{a}}$ & $13.8^{\mathrm{b}}$ & $19.8^{\mathrm{a}}$ & $19.7^{\mathrm{a}}$ & 0.5 \\
\hline $16: 1 n-7$ & $0.6^{\mathrm{a}}$ & $0.9^{\mathrm{b}}$ & $0.6^{\mathrm{a}}$ & $0.5^{\mathrm{a}}$ & 0.1 \\
\hline 18:0 & $13.6^{\mathrm{a}}$ & $28.5^{\mathrm{b}}$ & $13.6^{\mathrm{a}}$ & $12.7^{\mathrm{a}}$ & 0.3 \\
\hline $18: 1 n-9$ & 15.4 & 16.6 & 15.3 & 15.9 & 0.5 \\
\hline $18: 1 \mathrm{n}-7$ & $4.8^{\mathrm{a}}$ & $2.5^{\mathrm{b}}$ & $4.8^{\mathrm{a}}$ & $5.0^{\mathrm{a}}$ & 0.1 \\
\hline $18: 2 n-6$ & $24.8^{\mathrm{a}}$ & $20.9^{\mathrm{b}}$ & $25.1^{\mathrm{a}}$ & $25.5^{\mathrm{a}}$ & 0.5 \\
\hline $18: 3 n-3$ & $1.4^{\mathrm{a}}$ & $1.4^{\mathrm{a}}$ & $1.8^{\mathrm{b}}$ & $1.9^{\mathrm{b}}$ & 0.1 \\
\hline $20: 3 n-6$ & $0.9^{\mathrm{a}}$ & $1.5^{\mathrm{b}}$ & $1.0^{\mathrm{a}}$ & $0.8^{\mathrm{a}}$ & 0.1 \\
\hline $20: 4 n-6$ & 7.0 & 6.7 & 7.1 & 7.1 & 0.3 \\
\hline $20: 5 n-3$ & $2.8^{\mathrm{ac}}$ & $3.3^{\mathrm{b}}$ & $3.1^{\mathrm{ab}}$ & $2.7^{\mathrm{c}}$ & 0.1 \\
\hline $22: 5 n-3$ & $1.7^{\mathrm{a}}$ & $1.3^{\mathrm{b}}$ & $1.8^{\mathrm{a}}$ & $1.7^{\mathrm{a}}$ & 0.1 \\
\hline $22: 6 n-3$ & $3.6^{\mathrm{a}}$ & $1.3^{\mathrm{b}}$ & $3.5^{\mathrm{a}}$ & $3.4^{\mathrm{a}}$ & 0.15 \\
\hline \multicolumn{6}{|c|}{ Triacylglycerols } \\
\hline 10:0 & nd & nd & nd & nd & \\
\hline $14: 0$ & 1.3 & 1.3 & 1.3 & 1.3 & 0.1 \\
\hline $16: 0$ & 24.0 & 23.1 & 23.8 & 22.9 & 0.6 \\
\hline $16: 1 \mathrm{n}-7$ & $3.9^{\mathrm{a}}$ & $4.5^{\mathrm{b}}$ & $4.6^{\mathrm{b}}$ & $4.9^{\mathrm{b}}$ & 0.3 \\
\hline 18:0 & $8.9^{\mathrm{a}}$ & $8.7^{\mathrm{a}}$ & $8.8^{\mathrm{a}}$ & $7.1^{b}$ & 0.4 \\
\hline $18: 1 n-9$ & $39.7^{\mathrm{a}}$ & $39.8^{a}$ & $39.4^{b}$ & $41.2^{\mathrm{ab}}$ & 0.6 \\
\hline $18: 1 n-7$ & 4.4 & 4.4 & 4.5 & 4.6 & 0.1 \\
\hline $18: 2 n-6$ & 12.4 & 12.2 & 11.8 & 12.3 & 0.3 \\
\hline $18: 3 n-3$ & 2.1 & 2.6 & 2.5 & 2.7 & 0.2 \\
\hline $20: 3 n-6$ & 0.4 & 0.3 & 0.4 & 0.4 & 0.1 \\
\hline $20: 4 n-6$ & $0.4^{\mathrm{ab}}$ & $0.4^{\mathrm{a}}$ & $0.4^{\mathrm{a}}$ & $0.3^{\mathrm{b}}$ & 0.0 \\
\hline $20: 5 n-3$ & 0.3 & 0.3 & 0.2 & 0.2 & 0.0 \\
\hline $22: 5 n-3$ & 0.4 & 0.4 & 0.4 & 0.3 & 0.0 \\
\hline $22: 6 n-3$ & $0.7^{\mathrm{a}}$ & $0.7^{\mathrm{a}}$ & $0.7^{\mathrm{a}}$ & $0.5^{\mathrm{b}}$ & 0.1 \\
\hline
\end{tabular}

${ }^{1}$ values represent LS-means \pm SEM $(n=6)$

${ }^{2}$ nd: not detectable

fatty acids represented with less than $1 \mathrm{~mole} \%$ in both the phospholipid and

triacylglycerol fractions are not shown

total fatty acids identified equals $100 \mathrm{~mole} \%$

values in a row without common superscript letters are different $(\mathrm{P}<0.05)$ 
舀

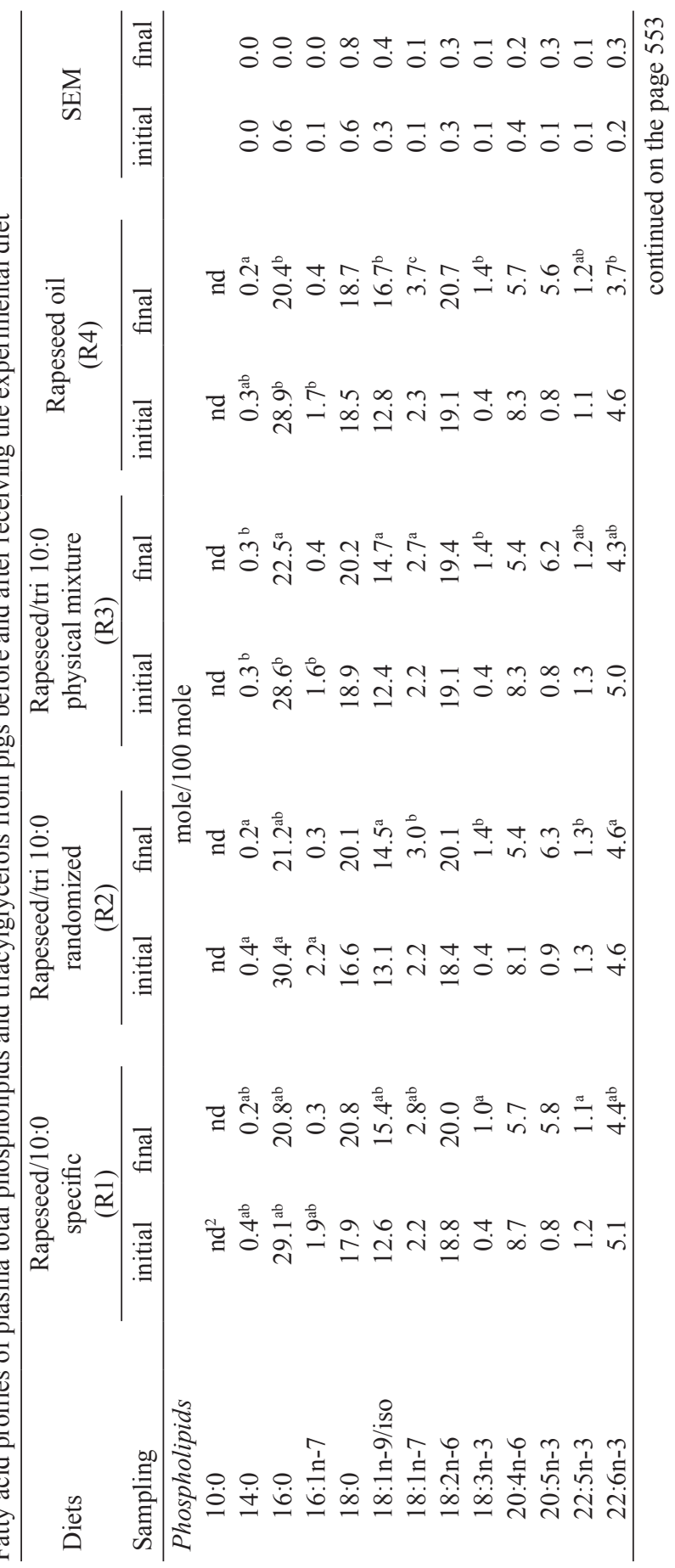


continued on the page 553

STRAARUP E.M. ET AL.

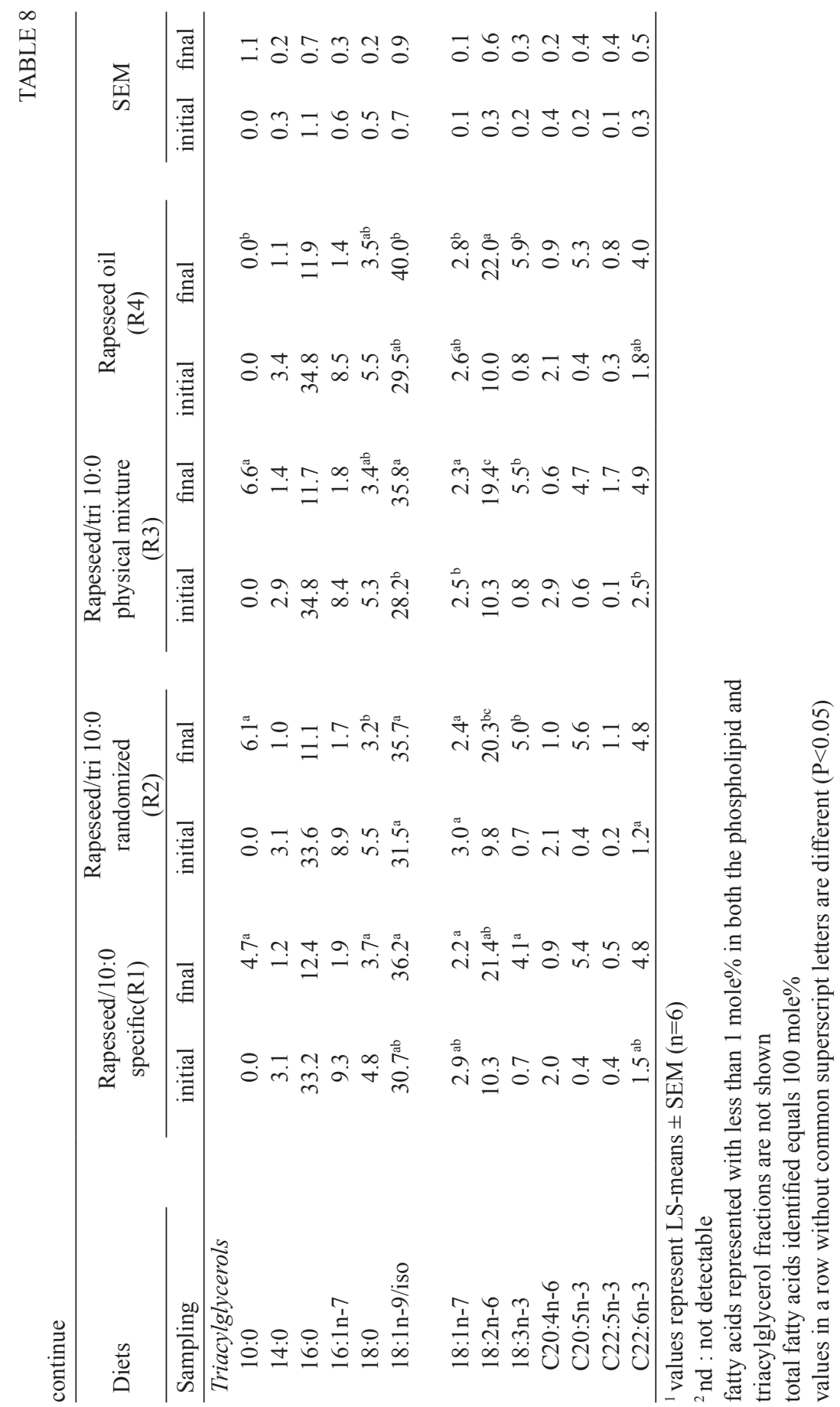


in the proportions of 18:2n-6 and 18:3n-3 were also observed. These differences reflected either the fatty acid profile or the structure of the test oils.

Erythrocyte membrane. The profiles of total fatty acids of erythrocyte membranes differed between the four groups, at the start of the experiment for 12:0, 16:0 aldehyde, 16:0 and 18:1n-7 (Table 9). The differences between the groups were most pronounced for 16:0 aldehyde and 16:0. At the end of the experiment significant differences in fatty acid profiles were observed for 18:3n-3, 20:3n-6 and 20:4n-6, with the highest proportion of 18:3n-3 in the R3 group and the proportions of $20: 3 n-6$ and 20:4n-6 were higher in the R4 group compared to the other groups. Although, 10:0 was present in relative high proportions in the test fats R1-R3, 10:0 was not detectable in the erythrocyte membranes in these groups. Also, 12:0, which was present initially in R2 and R4, totally vanished during the experimental period.

\section{DISCUSSION}

Failing adaptation to dietary changes post-weaning may delay growth, induce diarrhoea or cause premature death of piglets. The sow's milk has a high fat level. In spite of this the activity of pancreatic lipase in piglets is low during the suckling period (Pettigrew et al., 1986; Jensen et al., 1997), whereas that of gastric lipase is high (Jensen et al., 1997). During the first weeks post-weaning the activity of the pancreatic lipase decreases followed by an increase after adaptation to the new diet (Cera et al., 1990a; Jensen et al., 1997). Pierzynowski et al. (1993) showed that the age of piglets at weaning is of minor importance. The low pancreatic lipase activity at weaning may result in low fat absorption and thereby reduced energy availability, resulting in low nitrogen gain in the post-weaning period. To improve the nitrogen gain, it is necessary to improve the fat absorption to supply the piglet with more energy (Chwalibog et al., 1994). Addition of maize oil to the feed did not improve the survival rate of newborn piglets (Pettigrew et al., 1986). However, for piglets of low birth weight, death was delayed, suggesting a benefit of the fat addition. Cera et al. (1990b) demonstrated a higher apparent fat digestibility in piglets weaned at 21 days of age fed medium-chain triacylglycerols and a higher nitrogen retention in piglets fed medium-chain triacylglycerols or coconut oil during the initial 2 weeks post-weaning compared to piglets fed soyabean oil.

The present study demonstrated improved fat digestibility and nitrogen retention in post-weaning piglets fed diets containing structured fats (R1 and R2) followed by the R3 diet (physical mixture) compared to the R4 diet (native rapeseed oil). These results indicate improved utilization of the fats containing 10:0 compared to the R4 oil, probably because of the readily available energy from the oxidation of 10:0 (Innis et al., 1993) followed by an increase in utilization or deposition of dietary nitrogen (Tauson et al., 1998). 


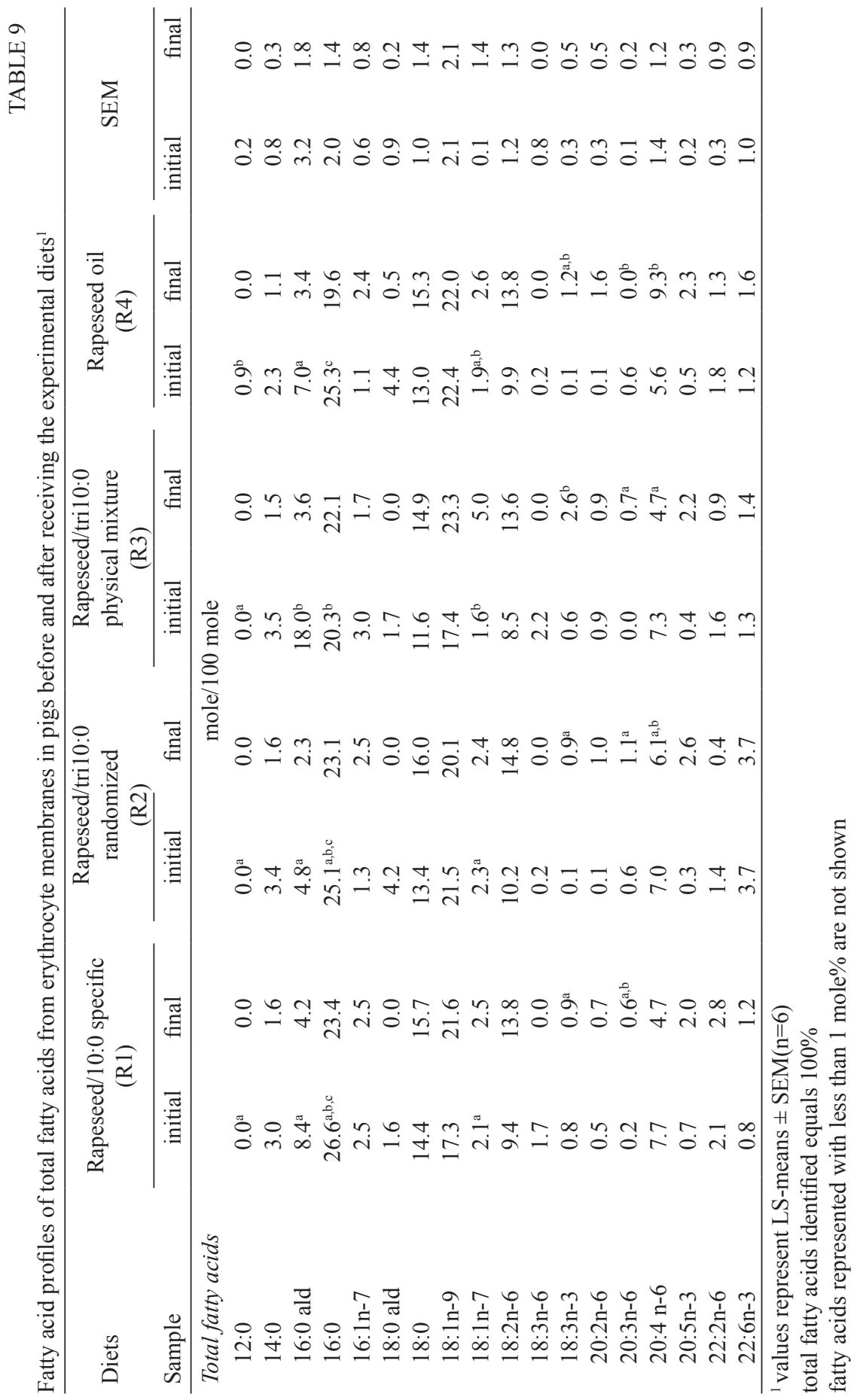


That dietary 10:0 probably was oxidized in the body to a major extent is further demonstrated by its absence in virtually all the tissues investigated except in triacylglycerols of adipose tissue. Similar results have been found for 10:0 and 12:0 fed to pigs as coconut fat, although 12:0 was found in small proportions (Madsen et al., 1992). As reviewed by Jakobsen (1999) backfat of pigs fed a virtually fat-free diet contains no detectable amounts of 10:0 and very small proportions of 12:0 (0.1\%) and 14:0 (1.4\%), whereas $16: 0(16 \%)$ and notably $18: 1(62 \%)$ are the major fatty acids, but the fatty acid composition is readily influenced by the dietary fatty acid profile especially by long-chain polyunsaturated fatty acids. The presence of 10:0 in the diets resulted in a relatively higher proportion of exogenous long-chain fatty acids in tissues and plasma than with the diet without 10:0. Innis et al. (1993) suggested that dietary medium-chain fatty acids were transported by the portal vein to the liver for oxidation and that this resulted in a higher tissue retention of $18: 1,18: 2 n-6$ and 18:3n-3. This suggestion was made because these fatty acids had higher proportions in adipose tissue from pigs fed diets with 8:0 and 10:0, and to a lesser extent 12:0 and 14:0, than those containing 16:0. This is in accordance with the results by Odle et al. (1991) who observed medium-chain fatty acids in the jugular plasma one hour after feeding a medium-chain fatty acidrich diet. The proportion of medium-chain fatty acids in the blood decreased with increasing chain length.

Results in the present study showed overall that the fatty acid profile of the test fat was reflected in the fatty acids in the liver, adipose tissue and skeletal muscle, except for phospholipids from adipose tissue where the proportion of 18:1 in the sn-2 position was reflected. No major differences in the fatty acid profile of total plasma, erythrocyte membranes, liver, adipose tissue and skeletal muscle were observed between the four groups, although the proportion of long-chain fatty acids were higher in the native oil than in the manufactured oils. This was probably because the utilization of medium-chain fatty acids for energy production spared the long-chain fatty acids from oxidation, and the demand for fatty acids to tissue formation could be met by the long-chain fatty acids in the manufactured oils and their conversion products. This partly agrees with the observation made by Innis et al. (1993) of a higher retention of 18:1, 18:2n-6 and 18:3n-3 from fat containing 8:0 and 10:0 compared to $16: 0$.

The increased proportion of 20:5n-3 and decreased proportion of 20:4n-6 in blood lipids observed at the end of the experiment, may result from elongation of 18:3n-3 to 20:5n-3 (Brenner, 1974; Rioux and Innis, 1992) which inhibits the desaturation and chain elongation of 18:2n-6 to 20:4n-6, and competes with 20:4n-6 for acylation into phospholipids (Wall et al., 1994).

Compared to previous investigations, we extended the present examination to include more types of fats based on medium-chain fatty acids and rapeseed oil. The results emphasize that the fatty acid profile of the dietary fat, even if manipu- 
lated as to the specific position of fatty acids in the triacylglycerol molecule, determines the fatty acid profile in plasma, erythrocyte membranes, liver, adipose tissue and skeletal muscle, in the same way as native fat and oils as reviewed comprehensively by Jakobsen (1999). However, the presence of medium-chain fatty acids in the manufactured oils resulted in increased fat digestibility and nitrogen retention compared to the native rapeseed oil supporting the hypothesis that dietary 10:0 was mainly oxidized supporting the energy requirement for growth in fast growing piglets.

\section{ACKNOWLEDGMENTS}

We thank Flemming Kejser (BioCentrum-DTU, Biochemistry and Nutrition, Technical University of Denmark) and Marie Lilleris (Danish Institute of Agricultural Sciences, Research Centre Foulum, Department of Animal Nutition and Physiology) for technical assistance and $\mathrm{S}$. Balchen $\mathrm{PhD}$. and X. Xu, PhD., BioCentrum-DTU, Technical University of Denmark, for performing the interesterifications and the mixing of fats.

\section{REFERENCES}

AOAC, 1990. Official Methods of Analysis, Association of Official Analytical Chemists. 15th Edition. Arlington, VA

Becker C.C., Rosenquist A., Holmer G., 1993. Regiospecific analysis of triacylglycerols using allyl magnesium bromide. Lipids 28, 147-149

Bligh E.G., Dyer W.J., 1959. A rapid method of total lipid extraction and purification. Can. J. Biochem. Physiol. 37, 911-917

Brenner R.R., 1974. The oxidative desaturation of unsaturated fatty acids in animals. Mol. Cell. Biochem. 3, 41-52

Cera K.R., Mahan D.C., Reinhart G.A., 1990a. Effect of weaning, week postweaning and diet composition on pancreatic and small intestinal luminal lipase response in young swine. J. Anim. Sci. 68, 384-391

Cera K.R., Mahan D.C., Reinhart G.A., 1990b. Evaluation of various extacted vegetable oils, roasted soybeans, medium-chain triglyceride and an animal-vegetable fat blend for postweaning swine. J. Anim. Sci. 68, 2756-2765

Chiang S.H., Pettigrew J.E., Clarke S.D., Cornelius S.G., 1990. Limits of medium-chain and longchain triacylglycerol utilization by neonatal piglets. J. Anim. Sci. 68, 1632-1638

Christensen M.S., Müllertz A., Нøy C., 1995. Absorption of triglycerides with defined or random structure by rats with biliary and pancreatic diversion. Lipids 30, 521-526

Christopherson S.W., Glass R.L., 1969. Preparation of milk fat methyl esters by alcoholysis in an essential nonalcoholic solution. J. Dairy Sci. 52, 1289-1290

Chwalibog A., Jakobsen K., Thorbek G., 1994. Loss of body fat in piglets in spite of gain in live weight. J. Anim. Physiol. Anim. Nutr. 72, 80-85 
DeNigris S.J., Hamosh M., Kasbekar D.K., Lee T.C., Hamosh P., 1988. Lingual and gastric lipases: species differences in the origin of prepancreatic digestive lipases and in the localization of gastric lipase. Biochim. Biophys. Acta 959, 38-45

Folch J., Lees M., Stanley G.H S., 1957. A simple method for the isolation and purification of total lipids from animal tissue. J. Biol. Chem. 226, 497-509

Innis S.M., King J.D., Dyer R.D., Quinlan P., Diersen-Schade D., 1993. Adipose tissue fatty acids of piglets fed formulae varying in saturated and monounsaturated fatty acids, linoleic and linolenic acid, and with longer chain $n-3$ fatty acids from fish oil. Nutr. Res. 13, 929-940

Jakobsen K., 1990. Linolsäurebedarf des Schweines. Fat Sci.Technol. 92, 547-551

Jakobsen K., 1999. Dietary modifications of animal fats: status and future perspectives. Fett/Lipid $101,475-483$

Jandacek R.J., Whiteside J.A., Holcombe B.N., Volpenhein R.A., Taulbee J.D., 1987. The rapid hydrolysis and efficient absorption of triglycerides with octanoic acid in the 1 and 3 positions and long-chain fatty acid in the 2 position. Amer. J. Clin. Nutr. 45, 940-945

Jensen M.S., Jensen S.K., Jakobsen K., 1997. Development of digestive enzymes in pigs with emphasis on lipolytic activity in the stomach and pancreas. J. Anim. Sci. 75, 437-445

Madsen A., Jakobsen K., Mortensen H.P., 1992. Influence of dietary fat on carcass fat quality. A review. Acta Agr. Scand., Sect. A., Anim. Sci. 42, 220-225

Morrison W.R., Smith L.M., 1964. Preparation of fatty acid methyl esters and dimethylacetals from lipids with boron fluoride-methanol. J. Lipid Res. 5, 600-608

Odle J., Benevenga N.J., Crenshaw T.D., 1991. Utilization of medium-chain triglycerides by neonatal piglets: chain length of even- and odd-carbon fatty acids and apparent digestion/absorption and hepatic metabolism. J. Nutr. 121, 605-614

Pettigrew J.E., 1981. Supplemental dietary fat for peripartal sows: a reviev. J. Anim. Sci. 53, 107-117

Pettigrew J.E., Cornelius S.G., Moser R.L., Heeg T.R., Hanke H E., Miller K.P., Hagen C.D., 1986. Effects of oral doses of corn oil and other factors on preweaning survival and growth of piglets. J. Anim. Sci. 62, 601-612

Pierzynowski S.G., Wetsröm B.R., Erlanson-Albertsson C., Ahreń B., Svendsen J., Karlsson B.W., 1993. Induction of exocrine pancreas maturation at weaning in young developing pigs. J. Pediatr. Gastroenterol. Nutr. 16, 287-293

Rioux F.M., Innis S.M., 1992. Arachidonic acid concentrations in plasma and liver phospholipid and cholesterol esters of piglets raised on formulas with different linoleic and linolenic acid contents. Amer. J. Clin. Nutr. 56, 106-112

SAS ${ }^{\circledR}$. SAS/STAT Guide for Personal Computers. Version 6. 1987. Gary, NC, USA, SAS Institute Inc.

Stoldt W., 1952. Vorschlag zur Vereinheitlichung der Fettbestimmung in Lebendsmitteln. Fette u. Seifen 54, 206-207

Tauson A.H., Chwalibog A., Jakobsen K., Thorbek G., 1998 Pattern of protein retention in growing boars of different breeds, and estimation of maximum protein retention. Arch. Anim. Nutr. 51, 253-262

Teo T.C., DeMichele S.J., Selleck K.M., Babayan V.K., Blackburn G.L., Bistrian B.R., 1989. Administration of structured lipid composed of MCT and fish oil reduces net protein catabolism in enterally fed burned rats. Ann. Surg. 210, 100-107

The National Committee for Pig Breeding, Health and Production, 1997. Guidelines for Pigs (in Danish). The National Commitee of Pig Breeding, Health and Production, Danish Bacon and Meat Council, Axelborg, Copenhagen (Denmark), pp. 4

Wall K.M., Diersen-Schade D., Innis S.M., 1994. Plasma and tissue lipids of piglets fed formula containing saturated fatty acids from medium-chain triglycerides with or without fish oil. Amer. J. Clin. Nutr. 59, 1317-1324 
Xu X., Balchen S., Hoy C.-E., Adler-Nissen J., 1998. Pilot batch production of specific-structured lipids by lipase-catalyzed interesterification: Preliminary study on incorporation and acyl migration. JAOCS 75, 301-308

\section{STRESZCZENIE}

Strawność tłuszczu, retencja azotu i profil kwasów thuszczowych w krwi i tkankach odsadzonych prosiąt otrzymujących tluszcze wewnętrznie estryfikowane

Badano wpływ skarmiania tłuszczu o zmienionej strukturze, w porównaniu ze strukturą glicerydów zawartych w zwykłej diecie, na strawność składników pokarmowych, retencję azotu oraz profil kwasów tłuszczowych w plazmie krwi, błonie erytrocytów, wątrobie, tkance tłuszczowej i mięśniach szkieletowych u 24 odsadzonych prosiąt, podzielonych na 4 grupy. Testowane tłuszcze dodawano do diety w ilości 10\% (w/w): R1 - tłuszcze o specyficznej strukturze z kwasem dekanowym (10:0) umiejscowionym głównie w pozycjach sn-1/3 i długołańcuchowym kwasem oleju rzepakowego w pozycji sn-2; R2 - podobny tłuszcz, ale poddany chemicznej randomizacji; R3 - mieszanina fizyczna tłuszczu zawierającego w cząsteczce 3 kwasy z olejem rzepakowym; R4 - olej rzepakowy. Po odsadzeniu w 28 dniu życia i po jednym tygodniu adaptacji prosięta umieszczono w klatkach metabolicznych i przez 3 kolejne 7-mio dniowe okresy kolekcji zbierano ilościowo kał i mocz celem oznaczenia strawności składników pokarmowych i energii oraz retencji azotu. Strawność tłuszczu i retencja azotu były istotnie większe $(\mathrm{P}<0,05)$ przy dodaniu syntetyzowanych olejów zawierających kwas dekanowy (grupy R1-R3) w porównaniu z olejem rzepakowym (grupa R4), przy czym największą reakcję stwierdzono przy dodatku oleju zawierającego kwas dekanowy w pozycjach sn-1/3 (grupa R1). Profil kwasów tłuszczowych w badanych tkankach odzwierciedlał profil badanych tłuszczów z wyjątkiem kwasu dekanowego, który wystąpił tylko w trójglicerolach tkanki tłuszczowej i w plazmie krwi prosiąt z grup R1-R3; wskazuje to, że kwas dekanowy był głównie utleniany dostarczając energii do tworzenia białka. 